\title{
Current Management and Controversies of Juvenile Angiofibromas
}

\author{
${ }^{1}$ Colin R Butler, ${ }^{2}$ Daniel W Scholfield, ${ }^{3}$ Gitta Madani, ${ }^{4}$ Ann Sandison, ${ }^{5}$ Peter M Clarke
}

\begin{abstract}
Juvenile angiofibromas are benign, highly vascular lesions that are found in young male patients with an incidence of approximately $1: 150,000$. They are thought to arise from a residual vascular plexusin the pterygopalatine fossa at the aperture of the pterygoid canal, as a remnant of the involution of the first branchial arch artery. Juvenile angiofibromas remain challenging to treat. Early staged disease can be adequately treated by endoscopic approaches and with increasing experience, even higher staged disease has been shown to be resectable
\end{abstract}

Keywords: Angiofibroma, Juvenile nasopharyngeal angiofibroma,

How to cite this article: Butler CR, Scholfield DW, Madani G, Sandison A, Clarke PM. Current Management and Controversies of Juvenile Angiofibromas. Int J Head Neck Surg 2018; $9(1): 32-37$.

\section{Source of support: Nil}

Conflict of interest: None

\section{BACKGROUND}

Juvenile angiofibromas (JAs) are benign, highly vascular lesions that are found in young male patients in the posterior nose and postnasal space arising from the posterolateral nasopharynx. They represent $0.05 \%$ of all head and neck tumors, with an incidence of approximately 1:150,000. ${ }^{1}$ Radiological studies have identified their anatomical origin in the pterygopalatine fossa at the aperture of the pterygoid (vidian) canal. ${ }^{2}$ They are thought to arise from a residual vascular plexus, as a

\footnotetext{
${ }^{1}$ Specialist Registrar, ${ }^{2}$ Trainee, ${ }^{3}$ Consultant Radiologist ${ }^{4}$ Consultant Pathologist, ${ }^{5}$ Consultant, Surgeon

1,2,5 Department of Ear Nose Throat Surgery, Charing Cross Hospital, Imperial College Healthcare NHS Trust, London UK

${ }^{3}$ Department of Radiology, Charing Cross Hospital, Imperial College Healthcare NHS Trust, London, UK

${ }^{4}$ Department of Histopathology, Charing Cross Hospital, Imperial College Healthcare NHS Trust, London, UK

Corresponding Author: Peter M Clarke, Consultant, Surgeon, Department of Histopathology, Charing Cross Hospital, Imperial College Healthcare NHS Trust London, UK, e-mail: peter. clarke@imperial.nhs.uk
}

remnant of the involution of the first branchial arch artery. ${ }^{3}$ A national retrospective cohort study reported a median age of 15 years (10-24 years). ${ }^{4}$ Hormonal influence on their growth is also supported by the presence of androgen receptors on their cell membranes ${ }^{5}$ and the suppressive effects of flutamide. ${ }^{6}$

Main presenting symptoms include unilateral nasal obstruction (80\%) and unprovoked unilateral epistaxis $(60 \%) .{ }^{2}$ Facial numbness, headaches, visual changes, and facial deformity can occur, depending on the extent of invasion. Nasal endoscopy typically reveals a lobulated, hypervascularized mass extending into the nasopharynx. The JAs are considered benign; however, they can invade and extend into the paranasal sinuses, orbit, cavernous sinus, and along the skull base. Forty percent present at an advanced stage and $17 \%$ of cases have intracranial involvement. ${ }^{7}$ The locally destructive characteristics, vascular nature, and $20 \%$ recurrence rate ${ }^{8}$ highlight the controversies surrounding management.

\section{PRINCIPLES OF WORKUP AND MANAGEMENT}

Biopsy is contraindicated in suspected JA due to the potential for catastrophic bleeding. Computed tomography (CT) is usually sufficient for diagnosis, characteristically revealing widening of the sphenopalatine foramen and extension into surrounding areas (Figs 1 and 2).

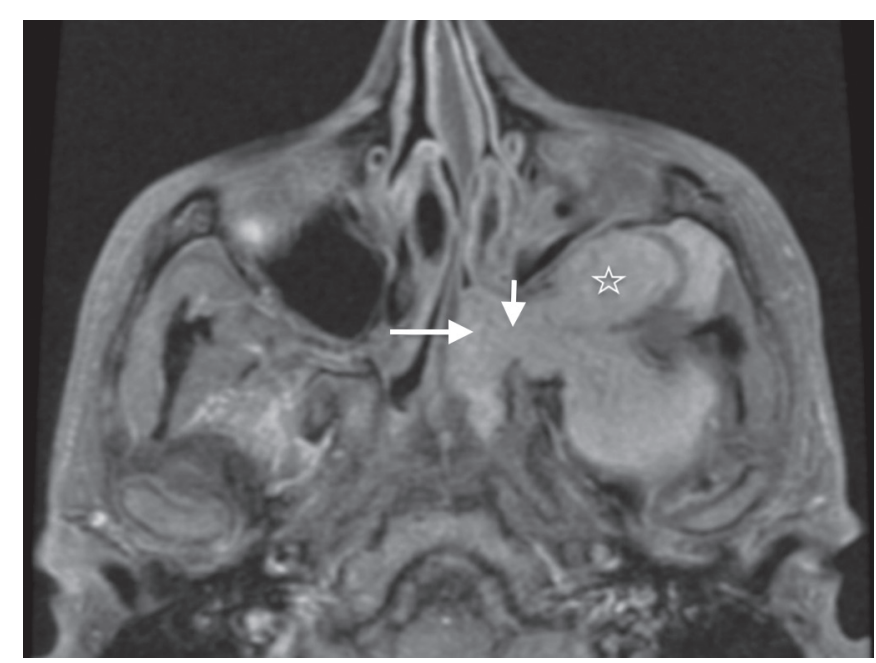

Fig. 1: Axial T1 fat-saturated postgadolinium image demonstrating enhancing tumor extending from the nasopharynx (long arrow), through the sphenopalatine foramen (short arrow) into the infratemporal fossa (stars) 

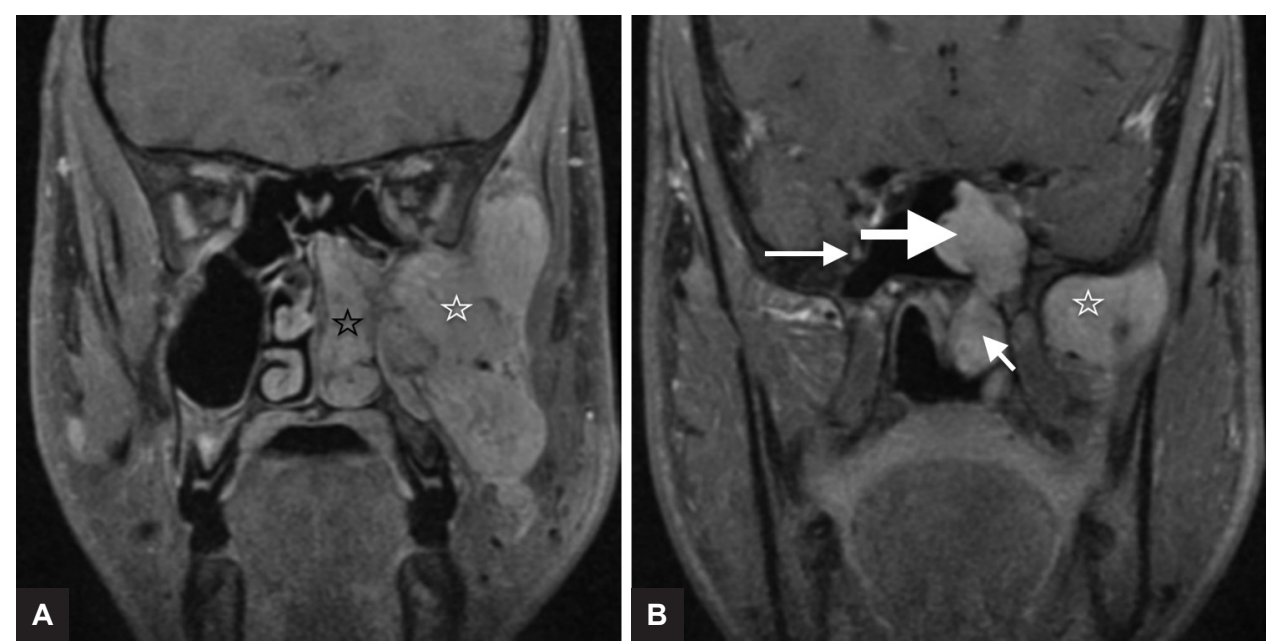

Figs 2A and B: Coronal T1 fat-saturated postgadolinium images of the same patient, demonstrating enhancing tumor in the nasal cavity (black star), nasopharynx (short white arrow), and sphenoid sinus (block arrow). Note the left vidian canal and foramen rotundum are destroyed and expanded by tumor (compare with the right vidian canal (back arrow) and foramen rotundum (long arrow))

Erosion of the upper medial pterygoid plate is pathognomonic, found in $98 \%$ of tumors. ${ }^{9}$ The CT is superior in distinguishing bony landmarks and sphenoid invasion, a significant factor in recurrence. ${ }^{2}$ Contrast-enhanced magnetic resonance imaging (MRI) often shows "flow voids" typical of this vascular lesion and can differentiate it from other inflammatory lesions. The MRI further delineates intracranial or bone marrow involvement. The $\mathrm{CT}$ angiogram can be considered invaluable, where the blood supply can be fully delineated. Often direct tributaries from the internal carotid can be identified with this imaging modality further which aids surgical planning. Histological features include stellate andstaghorn blood vessels with variable vessel wall thickness and Irregular fibrous stromacontaining stellate fibroblasts with small pyknotic to large vesicular nuclei (Figs 3 and 4).

There are multiple staging systems for JA (Table 1), predominantly focused on extent of invasion, the most advanced exhibiting intracranial extension. Traditionally,

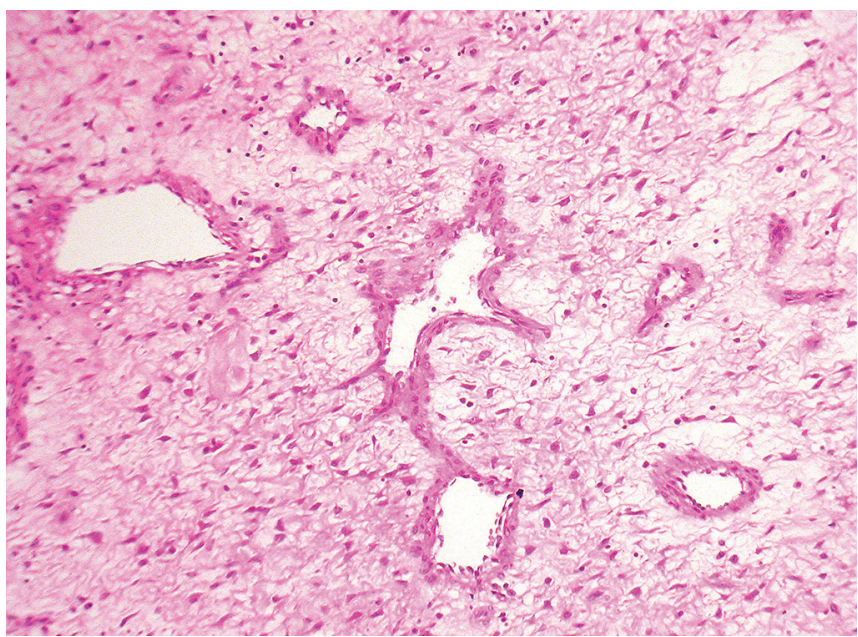

Fig. 3: Hematoxylin-eosin stain of juvenile angiofibroma $\times 100$ magnification the most popular systems are by Radkowski et al., ${ }^{10}$ Fisch, ${ }^{11}$ Andrews et al., ${ }^{12}$ and Chandler et al. ${ }^{13}$ (Table 1). However, the recently developed University of Pittsburgh Medical Center (UPMC) staging system ${ }^{14}$ focuses on prognostic factors for endoscopic surgery and questions which system is the most relevant to current management strategies.

Juvenile angiofibroma is predominantly a surgical lesion, with resection forming the mainstay of management in primary and recurrent disease, regardless of staging. Key preoperative decision-making centers on surgical approach and use of preoperative embolization, both of which shall be assessed in more detail below.

\section{CONTROVERSIES}

\section{Endoscopic vs Open Debate}

As with many surgical techniques, there has been a recent trend toward an endoscopic approach in the resection

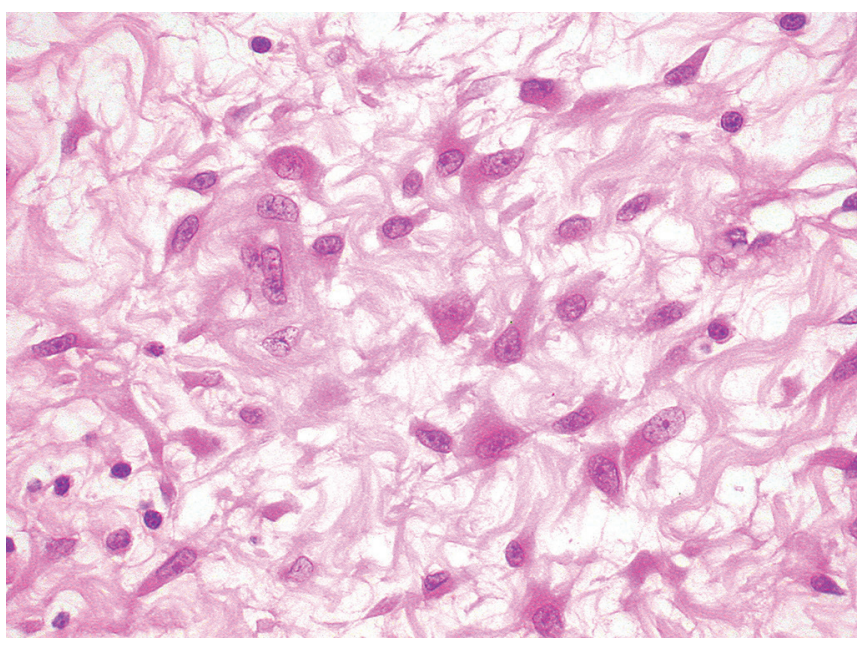

Fig. 4: Hematoxylin-eosin stain of juvenile angiofibroma $\times 500$ magnification 
Table 1: Staging of juvenile angiofibroma

\begin{tabular}{|c|c|c|c|c|c|}
\hline Stage & Fisch $^{11}$ & Chandler et al. ${ }^{13}$ & Andrews et al. ${ }^{12}$ & Radkowski et al. ${ }^{10}$ & Snyderman et al. ${ }^{14}$ \\
\hline I & $\begin{array}{l}\text { Limited to the } \\
\text { nasopharyngeal cavity; } \\
\text { bone destruction } \\
\text { negligible or limited } \\
\text { to the sphenopalatine } \\
\text { foramen }\end{array}$ & $\begin{array}{l}\text { Confined to the } \\
\text { nasopharynx }\end{array}$ & $\begin{array}{l}\text { Limited to the } \\
\text { nasopharyngeal cavity; } \\
\text { bone destruction } \\
\text { negligible or limited } \\
\text { to the sphenopalatine } \\
\text { foramen }\end{array}$ & $\begin{array}{l}\text { la: Limited to the } \\
\text { posterior nares and/or } \\
\text { nasopharyngeal vault } \\
\text { lb: With involvement of at } \\
\text { least one paranasal } \\
\text { sinus }\end{array}$ & $\begin{array}{l}\text { Nasal cavity, medial } \\
\text { pterygopalatine } \\
\text { fossa }\end{array}$ \\
\hline II & $\begin{array}{l}\text { Invading the } \\
\text { pterygopalatine fossa or } \\
\text { the maxillary, ethmoid, } \\
\text { or sphenoid sinus with } \\
\text { bone destruction }\end{array}$ & $\begin{array}{l}\text { Extends to the } \\
\text { nasal cavity and/or } \\
\text { sphenoid }\end{array}$ & $\begin{array}{l}\text { Invading the } \\
\text { pterygopalatine fossa } \\
\text { or the maxillary, } \\
\text { ethmoid, or sphenoid } \\
\text { sinus with bone } \\
\text { destruction }\end{array}$ & $\begin{array}{l}\text { Illa: } \text { Minimal lateral } \\
\text { extension to the } \\
\text { pterygomaxillary fossa } \\
\text { Ilb: Full occupation of the } \\
\text { pterygomaxillary fossa } \\
\pm \text { superior erosion } \\
\text { orbital bones } \\
\text { Ilc: Extension into the } \\
\text { infratemporal fossa or } \\
\text { pterygoid plates }\end{array}$ & $\begin{array}{l}\text { Paranasal } \\
\text { sinuses, lateral } \\
\text { pterygopalatine } \\
\text { fossa; no residual } \\
\text { vascularity }\end{array}$ \\
\hline III & $\begin{array}{l}\text { Invading the } \\
\text { infratemporal fossa or } \\
\text { orbital region } \\
\text { (a) Without intracranial } \\
\text { involvement } \\
\text { (b) With intracranial } \\
\text { extradural } \\
\text { (parasellar) } \\
\text { involvement }\end{array}$ & $\begin{array}{l}\text { Extends to one } \\
\text { or several of } \\
\text { the following: } \\
\text { antrum, ethmoids, } \\
\text { pterygomaxillary } \\
\text { and infratemporal } \\
\text { fossa, orbit and/or } \\
\text { cheek }\end{array}$ & $\begin{array}{l}\text { Invading the } \\
\text { infratemporal fossa or } \\
\text { orbital region } \\
\text { (a) Without intracranial } \\
\text { involvement } \\
\text { (b) With intracranial } \\
\text { extradural } \\
\text { (parasellar) } \\
\text { involvement }\end{array}$ & $\begin{array}{l}\text { IIla Erosion of the } \\
\text { skull base (middle } \\
\text { cranial fossa/base of } \\
\text { pterygoids) - minimal } \\
\text { intracranial extension } \\
\text { IIIb Extensive intracranial } \\
\text { extension } \pm \text { extension } \\
\text { into the cavernous } \\
\text { sinus }\end{array}$ & $\begin{array}{l}\text { Skull base erosion, } \\
\text { orbit, infratemporal } \\
\text { fossa; no residual } \\
\text { vascularity }\end{array}$ \\
\hline IV & $\begin{array}{l}\text { Intracranial intradural } \\
\text { tumor } \\
\text { (a) Without infiltration of } \\
\text { the cavernous sinus, } \\
\text { pituitary fossa, or } \\
\text { optic chiasm } \\
\text { (b) With infiltration of } \\
\text { the cavernous sinus, } \\
\text { pituitary fossa, or } \\
\text { optic chiasm }\end{array}$ & $\begin{array}{l}\text { Extends into the } \\
\text { cranial cavity }\end{array}$ & $\begin{array}{l}\text { Intracranial intradural } \\
\text { tumor } \\
\text { (a) Without infiltration of } \\
\text { the cavernous sinus, } \\
\text { pituitary fossa, or } \\
\text { optic chiasm } \\
\text { (b) With infiltration of } \\
\text { the cavernous sinus, } \\
\text { pituitary fossa, or } \\
\text { optic chiasm }\end{array}$ & & $\begin{array}{l}\text { Skull base erosion, } \\
\text { orbit, infratemporal } \\
\text { fossa; residual } \\
\text { vascularity }\end{array}$ \\
\hline V & & & & & $\begin{array}{l}\text { Intracranial } \\
\text { extension, residual } \\
\text { vascularity; M, medial } \\
\text { extension; L, lateral } \\
\text { extension }\end{array}$ \\
\hline
\end{tabular}

of JAs. This is demonstrated by Cloutier et al., ${ }^{15}$ who reported a $45 \%$ rate of endoscopic resection in one center from 2000 to 2005, increasing to $82.9 \%$ over the following 5 years. $\mathrm{Kamel}^{16}$ was the first to publish a transnasal endoscopic approach that was recommended for JAs limited to nasopharynx, nasal cavity, and ethmoid and sphenoid sinuses. Advances in surgical technique, endoscopic equipment, imaging, and intraoperative navigation systems have made endoscopic resection an option for intracranial invasion in experienced hands. ${ }^{7,17}$

Transnasal endoscopic approach was initially used for early-stage disease and with increasing experience has naturally been used for stage IIIa and IIIb JAs. Evidence for the efficacy of the endoscopic approach has been described by Khoueir et al., ${ }^{18}$ where 54 intracranial cases of JA had been successfully resected by endoscopy alone. The approach has undeniable value in managing early and carefully selected advanced disease, avoids facial incisions, osteotomies, and even allows access to deep and lateral areas, such as the clivus and infratemporal fossa. Tumor involvement of the roof of the cavernous sinus or roof of the infratemporal fossa can be difficult to assess endoscopically and lead to incomplete resection. In these circumstances, some centers have suggested combining an endoscopy with an open craniofacial approach., ${ }^{719}$

A wide array of open surgical approaches have been described, including midfacial degloving, transpalatal, LeFort I osteotomies, lateral rhinotomy, transfacial, craniofacial, and infratemporal approaches. ${ }^{14}$ Midfacial degloving entertains popularity in comparison with lateral rhinotomy due to its avoidance of facial scars and provision of access through both the nasal cavity and maxillary sinus. Augmentation is possible with the preauricular-subtemporal-infratemporal approach for tumors extending into the middle cranial fossa or craniofacial-subcranial approaches for tumors extending 
into the anterior fossa. ${ }^{20} \mathrm{~A}$ significant disadvantage of the transpalatal approach is its poor exposure of larger tumors and subsequent increased chance of recurrence. ${ }^{21}$ In contrast, the infratemporal craniofacial approach has been advocated in the removal of JAs with intracranial extensions, combined with subtemporal craniectomy. ${ }^{12,22}$ Successful resection of JAs is also described via Le Fort I osteotomies, which allow for resection of intracranial lesions, but have a $40 \%$ complication rate in advanced JAs. ${ }^{23}$ Our unit considers even the most advanced JAs to be resectable via midfacial degloving, although in widespread recurrent disease this may, in rare circumstances, need to be augmented by combined approaches.

Hemostatic control with endoscopy has been previously considered challenging due to the limited access; however, a number of studies have indicated significantly less intraoperative blood loss with this method. ${ }^{20}$ A systematic review of 1,047 cases looked at the average blood loss for the endoscopic approach which was $544 \mathrm{~mL}$ compared with $1579.5 \mathrm{~mL}$ via open techniques. ${ }^{24}$ Intracranial involvement appears to be converse with an estimated blood loss (mean $1500 \mathrm{~mL}$ ) in open procedures, compared with a mean of $2998 \mathrm{~mL}$ observed during endoscopic resection $(p<0.05) .{ }^{7}$ As such, intracranial involvement may ultimately lead surgeons to choose an open approach.

Ensuring adequate resection is paramount in preventing recurrence. Endoscopy has the benefit of magnification and some authors consider it to improve ability to distinguish normal tissue from tumor. Studies have, however, remained inconclusive on this endoscopic benefit. Boghani et al's ${ }^{24}$ systematic review of published individual patient data concluded that although recurrence rates were less for endoscopic resections (10.8 vs $14.5 \%$ ), the difference was not significant. However, a significantly lower recurrence rate was reported endoscopically $(4.7 \%)$ in comparison with open resection (20.6\%) when the same systematic review looked at aggregate patient data (APD). It should be noted that the APD series is predominantly from single-center studies with large series and therefore, more experienced surgeons, which may explain why there is a significant difference in recurrence rates. The different open approaches are also not distinguished between, so it is not possible to tell whether some have better recurrence rates than others. ${ }^{23}$

\section{Embolization}

The benefits of minimizing intraoperative bleeding in JA resection include improved visualization and subsequent reduced chances of cerebrospinal fluid leak, cranial nerve and vascular injury. Poor visualization and excessive blood loss can ultimately prevent the complete removal of a lesion and require future staged resections. Blood transfusion and anemia have their own additional complications.

Most surgeons now endorse preoperative embolization of the branches of the external carotid artery (ECA) 24 to 48 hours before surgery with the aim of reducing intraoperative blood loss by up to $70 \% .^{20}$ This is supported by a systematic review that shows significantly lower blood loss in endoscopic cases, from an average of $828.3 \mathrm{~mL}$ without embolization to $406.7 \mathrm{~mL}$ with embolization. However, blood loss in the open group was significantly greater after preoperative embolization, perhaps due to the selection bias of larger tumors with more vascular involvement undergoing open resection. ${ }^{24}$ The branches of the internal carotid artery (ICA) are usually not embolized due to the increased risk of intracranial embolic events. Higher stage tumors and those with a blood supply from the ECA and ICA suffer significantly greater blood loss in comparison with smaller tumors and those supplied by ECA alone. ${ }^{25}$

Embolic substances used include coils, microparticles, liquid glue, polyvinyl alcohol, and an ethylene vinyl alcohol polymer, Onyx (ev3, Irvine, CA). The latter is statistically superior in reducing blood loss, reducing number of transfusions and increasing the number of lesions amenable to endoscopic resection when compared with particulate embolization. ${ }^{26,27}$ Additional advantages of Onyx include pigmentation of the tumor, more extensive tumor necrosis, embolization by fewer catheterizations, superior devascularization on angiograms, and no recurrence at follow-up. ${ }^{27}$

If the tumor feeding vessels cannot be safely embolized or are inaccessible, then further options include intratumoral embolization and surgical strategies, such as isolation and ligation of the internal maxillary artery, radiofrequency ablation, hypotensive anesthesia, division into vascular segments, diathermy of the sphenopalatine artery, cauterization of the vidian artery (the predominant feeding vessel of the ICA), and staging of surgery. ${ }^{20}$ However, preoperative embolization is not without its complications, including emboli causing ischemic events and amaurosis ${ }^{23}$ and vision loss due to central retinal artery occlusion. ${ }^{28,29}$ Some authors have proposed that embolization obscures the margins of JAs intraoperatively, leading to incomplete resection. ${ }^{30}$ It has also been linked to recurrence in sphenoid invasion, leading to the suggestion that this anatomical feature on imaging should be a contraindication to embolization. ${ }^{2}$

Despite its potential flaws, preoperative embolization has become an accepted standard that particularly augments the clear visual fields necessary in endoscopic resection. For larger and more invasive tumors, embolization may not be possible due to the high risk of stroke. In these 
cases, open surgery is not only indicated for adequate resection, but for hemostatic control during surgery.

\section{Staging}

Embolization of branches of the external carotid allows the remaining blood supply from branches of the ICA to be delineated and is accounted for in the UPMC staging system $^{14}$ (Table 1). Other popular staging systems by Radkowski et al., ${ }^{10}$ Fisch, ${ }^{11}$ Andrews et al., ${ }^{12}$ and Chandler et al. ${ }^{13}$ were established up to 20 years previously when open resection was the sole approach. These staging systems depend on the extent of invasion, with advanced stages being associated with skull base involvement and intracranial extension.

The UPMC staging system not only accounts for the vascularity of JAs but also the route of skull base extension. Its creators argue that UPMC staging can be applied to open and endonasal approach and found that residual vascularity after ICA (ECA) embolization (UPMC IV and V) correlated most strongly with blood loss, residual or recurrent tumor, and need for multiple procedures when compared with other staging systems. ${ }^{14,30}$ Preoperative embolization can thus effectively downstage tumors to a level associated with less perioperative risk. In two case series, they concluded that extent of disease and invasion of anatomical sites were less important in predicting complete resection with endonasal techniques. However, the review does not include open resection and has a median follow-up of 13.8 months. Other studies have shown the staging system by Andrews to correlate better with estimated surgical blood loss than UPMC ( $p<0.008$ vs $\mathrm{p}<0.015)$, which is also only applicable where embolization is implemented. Opposing results mean multicenter studies are required to determine if a single staging system is superior in modern-day practice.

\section{Management of Residual Disease and Recurrence}

Unresectable disease is uncommon in JA management, but extensive invasion into poorly accessible anatomical regions or encasement of neurovascular structures means that on occasion small amounts of tumor are left in situ. If residual disease is suspected or detected on imaging, some surgeons are aggressive in their approach and proceed to total tumor removal, while others monitor residual disease to reduce the risk of morbidity from multiple procedures. ${ }^{21}$ Magnetic resonance imaging is considered superior in postoperative monitoring due to its superior sensitivity in distinguishing postoperative changes from recurrence. ${ }^{20}$
Radiotherapy may be considered in unresectable advancing disease, with a regimen of 36 Gy at 1.8 Gy per treatment. ${ }^{31}$ However, the effectiveness of radiotherapy is limited and routine use in residual disease should be avoided due to long-term effects in a young population that include growth retardation, temporal lobe necrosis, ${ }^{32}$ and sarcomatous transformation. ${ }^{33}$ Intensity-modulated radiation therapy ${ }^{34}$ and proton beam therapy ${ }^{31}$ may help to reduce late radiation damage and offer superior target coverage, but are currently not supported by robust evidence in JA.

Recurrence of JAs commonly occurs early, between 12 and 24 months. ${ }^{2,21}$ Spontaneous regression has been observed $^{35,36}$ and therefore, in a benign lesion that may not progress, serial imaging, endoscopic examination, and close observation are acceptable follow-up strategies.

\section{CONCLUSION}

Juvenile angiofibromas remain challenging to treat and current controversies center around the optimal approach to ensure complete resection. Early staged disease can be adequately treated by endoscopic approaches and with increasing experience, even higher staged disease has been shown to be resectable. Open approaches are reserved for more invasive disease, particularly those with intracranial involvement. We would advocate open approaches for very extensive JA for access and for both hemostatic control and full resection of disease.

\section{REFERENCES}

1. Lund VJ, Stammberger H, Nicolai P, Castelnuovo P, Beal T, Beham A, Bernal-Sprekelsen M, Braun H, Cappabianca P, Carrau R, et al.; European Rhinologic Society Advisory Board on Endoscopic Techniques in the Management of Nose, Paranasal Sinus and Skull Base Tumours. European position paper on endoscopic management of tumours of the nose, paranasal sinuses and skull base. Rhinol (Suppl) 2010 Jun;22:1-143.

2. Lloyd G, Howard D, Phelps P, Cheesman A. Juvenile angiofibroma: the lessons of 20 years of modern imaging. J Laryngol Otol 1999 Feb;113(2):127-134.

3. Schick B, Urbschat S. New aspects of pathogenesis of juvenile angiofibroma. Hosp Med 2004 May;65(5):269-273.

4. Glad H, Vai ner B, Buchwald C, Petersen BL, Theilgaard SA, Bonvin P, Lajer C, Jakobsen J. Juvenile nasopharyngeal angiofibromas in Denmark 1981-2003: diagnosis, incidence, and treatment. Acta Otolaryngol 2007 Mar;127(3):292-299.

5. Hwang HC, Mills SE, Patterson K, Gown AM. Expression of androgen receptors in nasopharyngeal angiofibroma: an immunohistochemical study of 24 cases. Mod Pathol 1998 Nov;11(11):1122-1126.

6. Gates GA, Rice DH, Koopmann CF Jr, Schuller DE. Flutamide induced regression of angiofibroma. Laryngoscope 1992 Jun;102(6):641-644. 
7. Leong SC. A systematic review of surgical outcomes for advanced juvenile nasopharyngeal angiofibroma with intracranial involvement. Laryngoscope 2013 May;123(5): 1125-1131.

8. Stelow EB, Wenig BM. Update from the 4th edition of the World Health Organization classification of head and neck tumours: nasopharynx. Head Neck Pathol 2017 Mar;11(1):16-22.

9. Lloyd G, Howard D, Lund VJ, Savy L. Imaging for juvenile angiofibroma. J Laryngol Otol 2000 Sep;114(9):727-730.

10. Radkowski D, McGill T, Healy GB, Ohlms L, Jones DT. Angiofibroma: changes in staging and treatment. Arch Otolaryngol Head Neck Surg 1996 Feb;122(2):122-129.

11. Fisch $U$. The infratemporal fossa approach for nasopharyngeal tumors. Laryngoscope 1983 Jan;93(1):36-44.

12. Andrews JC, Fisch U, Valavanis A, Aeppli U, Makek MS. The surgical management of extensive nasopharyngeal angiofibromas with the infratemporal fossa approach. Laryngoscope 1989 Apr;99(4):429-437.

13. Chandler JR, Goulding R, Moskowitz L, Quencer RM. Nasopharyngeal angiofibromas: staging and management. Ann Otol Rhinol Laryngol 1984 Jul-Aug;93(4 Pt 1):322-329.

14. Snyderman CH, Pant H, Carrau RL, Gadner P. A new endoscopic staging system for angiofibromas. Arch Otolaryngol Head Neck Surg 2010 Jun;136(6):588-594.

15. Cloutier T, Pons Y, Blancal JP, Sauvaget E, Kania R, Bresson D, Herman P. Juvenile nasopharyngeal angiofibroma: does the external approach still make sense? Otolaryngol Head Neck Surg 2012 Nov;147(5):958-963.

16. Kamel RH. Transnasal endoscopic surgery in juvenile nasopharyngeal angiofibroma. J Laryngol Otol 1996 Oct;110(10):962-968.

17. Langdon C, Herman P, Verillaud B, Carrau RL, Prevedello D, Nicolai P, Schreiber A, Padoan G, Castelnuovo P, BernalSprekelsen M. Expanded endoscopic endonasal surgery for advanced stage juvenile angiofibromas: a retrospective multicentre study. Rhinology 2016 Sep;54(3):239-246.

18. Khoueir N, Nicolas N, Rohayem Z, Haddad A, Abou Hamad W. Exclusive endoscopic resection of juvenile nasopharyngeal angiofibroma: a systematic review of the literature. Otolaryngol Head Neck Surg 2014 Mar;150(3):350-358.

19. Carrau RL, Snyderman CH, Kassam AB, Jungreis CA. Endoscopic and endoscopic-assisted surgery for juvenile angiofibroma. Laryngoscope 2001 Mar;111(3):483-487.

20. López F, Triantafyllou A, Snyderman CH, Hunt JL, Suárez C, Lund VJ, Strojan P, Saba NF, Nixon IJ, Devaney KO, et al. Nasal juvenile angiofibroma: current perspectives with emphasis on management. Head Neck 2017 May;39(5):1033-1045.

21. Marshall AH, Bradley PJ. Management dilemmas in the treatment and follow-up of advanced juvenile nasopharyngeal angiofibroma. ORL J Otorhinolaryngol Relat Spec 2006 May;68(5):273-278.

22. Bales C, Kotapka M, Loevner LA, Al-Rawi M, Weinstein G, Hurst R, Weber RS. Craniofacial resection of advanced juvenile nasopharyngeal angiofibroma. Arch Otolaryngol Head Neck Surg 2002 Sep;128(9):1071-1078.

23. deMello-FilhoFV,Araujo FC, Marques Netto PB, Pereira-Filho FJ, de Toledo-Filho RC, Faria AC. Resection of a juvenile nasoangiofibroma by Le Fort I osteotomy: experience with 40 cases. J Craniomaxillofac Surg 2015 Oct;43(8): 1501-1504.

24. Boghani Z, Husain Q, Kanumuri VV, Khan MN, Sangvhi S, Liu JK, Eloy JA. Juvenile nasopharyngeal angiofibroma: a systematic review and comparison of endoscopic, endoscopicassisted, and open resection in 1047 cases. Laryngoscope 2013 Apr;123(4):859-869.

25. Ballah D, Rabinowitz D, Vossough A, Rickert S, Dunham B, Kazahaya K, Cahill AM. Preoperative angiography and external carotid artery embolization of juvenile nasopharyngeal angiofibromas in a tertiary referral paediatric centre. Clin Radiol 2013 Nov;68(11):1097-1106.

26. Gao M, Gemmete JJ, Chaudhary N, Pandey AS, Sullivan SE, McKean EL, Marentette LJ. A comparison of particulate and onyx embolization in preoperative devascularization of juvenile nasopharyngeal angiofibromas. Neuroradiology 2013 Sep;55(9):1089-1096.

27. Lutz J, Holtmannspötter M, Flatz W, Meier-Bender A, Berghaus A, Brückmann H, Zengel P. Preoperative embolization to improve the surgical management and outcome of juvenile nasopharyngeal angiofibroma (JNA) in a single center: 10-year experience. Clin Neuroradiol 2016 Dec;26(4): 405-413.

28. Ramezani A, Haghighatkhah H, Moghdasi H, Taheri MS, Parsafar $\mathrm{H}$. A case of central retinal artery occlusion following embolization procedure for juvenile nasopharyngeal angiofibroma. Indian J Ophthalmol 2010 Sep-Oct;58(5): 419-421.

29. Trivedi M, Desai RJ, Potdar NA, Shinde CA, Ukirde V, Bhuta M, Nair AG. Vision loss due to central retinal artery occlusion following embolization in a case of a giant juvenile nasopharyngeal angiofibroma. J Craniofac Surg 2015 Jul;26(5):e451-e453.

30. Mann WJ, Jecker P, Amedee RG. Juvenile angiofibromas: changing surgical concept over the last 20 years. Laryngoscope 2004 Feb;114(2):291-293.

31. Rowan NR, Zwagerman NT, Heft-Neal ME, Gardner PA, Snyderman $\mathrm{CH}$. Juvenile nasal angiofibromas: a comparison of modern staging systems in an endoscopic era. J Neurol Surg B Skull Base 2017 Feb;78(1):63-67.

32. Amdur RJ, Yeung AR, Fitzgerald BM, Mancuso AA, Werning JW, Mendenhall WM. Radiotherapy for juvenile nasopharyngeal angiofibroma. Pract Radiat Oncol 2011 Oct-Dec;1(4):271-278.

33. Lee JT, Chen P, Safa A, Juillard G, Calcaterra TC. The role of radiation in the treatment of advanced juvenile angiofibroma. Laryngoscope 2002 Jul;112(7 Pt 1):1213-1220.

34. Chen KT, Bauer FW. Sarcomatous transformation of nasopharyngeal angiofibroma. Cancer 1982 Jan;49(2):369-371.

35. Hodges JM, McDevitt AS, El-Sayed Ali AI, Sebelik ME. Juvenile nasopharyngeal angiofibroma: current treatment modalities and future considerations. Indian J Otolaryngol Head Neck Surg 2010 Sep;62(3):236-247.

36. Tosun F, Onerci M, Durmaz A, Ugurel S. Spontaneous involution of nasopharyngeal angiofibroma. J Craniofac Surg 2008 Nov;19(6):1686-1689. 